\title{
Arsenic trioxide inhibits the activity of SphK1 by decreasing the level of phosphatidylserine and phosphatidic acid in the human gastric cancer cell line MGC-803
}

\author{
Pei LIU; Zhe CHEN; Xiaoqiong MA* \\ Key Laboratory of Digestive Pathophysiology of Zhejiang Province, Institute of Cancer Research, First Affiliated Hospital, Zhejiang Chinese Medical University, \\ Hangzhou, 310006, China
}

Key words: $\mathrm{As}_{2} \mathrm{O}_{3}$, SphK1, PS, PA

\begin{abstract}
Sphingosine kinase 1 (SphK1) is an important synthetase during the synthesis of sphingosine-1-phosphate (S1P) from sphingosine $(\mathrm{Sph})$. Previous studies demonstrated that arsenic trioxide $\left(\mathrm{As}_{2} \mathrm{O}_{3}\right)$ could reduce the level of $\mathrm{S} 1 \mathrm{P}$ in human gastric cancer cell line MGC-803, indicating that $\mathrm{As}_{2} \mathrm{O}_{3}$ may inhibit the activity of SphK1. In this study, the effect of $\mathrm{As}_{2} \mathrm{O}_{3}$ on the SphK1 activation pathway was investigated. Western blot and quantitative real-time PCR analysis were used to evaluate the changes in protein and mRNA levels. The multi-dimensional mass spectrometry-based shotgun lipidomics method (MDMS-SL) was used for the quantitative detection of phosphatidylserine (PS) and phosphatidic acid (PA). The results revealed that $\mathrm{As}_{2} \mathrm{O}_{3}$ did not affect the protein and mRNA expression of SphK1 in the MGC-803 cells. However, $\mathrm{As}_{2} \mathrm{O}_{3}$ increased the levels of p-ERK1/2 and CIB1 in the SphK1 activation pathway and decreased the levels of PS and PA in the MGC-803 cells. The outcomes suggested that $\mathrm{As}_{2} \mathrm{O}_{3}$ may enhance the activity of SphK1 by increasing the levels of p-ERK1/2 and CIB1 and decrease the activity of SphK1 by decreasing the levels of PS and PA. It was suggested that the inhibition effect is stronger and resulting in an overall decrease in the activity of SphK1.
\end{abstract}

$\begin{array}{ll}\text { Abbreviations } \\ \text { As }_{2} \mathbf{O}_{3}: & \text { arsenic trioxide } \\ \text { CIB1: } & \text { calcium and integrin-binding protein } 1 \\ \text { FBS: } & \text { fetal bovine serum } \\ \text { LPA: } & \text { lysophosphatidic acid } \\ \text { MDMS-SL: } & \begin{array}{l}\text { multi-dimensional mass spectrometry-based } \\ \text { shotgun lipidomics }\end{array} \\ \text { MS: } & \text { mass spectrometry } \\ \text { NLS: } & \text { neutral loss scan } \\ \text { PA: } & \text { phosphatidic acid } \\ \text { p-ERK1/2: } & \text { phosphorylated extracellular signal-regulated } \\ & \text { kinase 1 and 2 } \\ \text { PIS: } & \text { precursor ion scan } \\ \text { PP2A: } & \begin{array}{l}\text { protein phosphatase 2A } \\ \text { phosphatidylserine }\end{array} \\ \text { PS: } & \begin{array}{l}\text { quantitative real-time polymerase chain } \\ \text { QPCR: }\end{array} \\ \text { S1P: } & \begin{array}{l}\text { reaction } \\ \text { sphingosine 1-phosphate }\end{array}\end{array}$

*Address correspondence to: Xiaoqiong Ma, mxq@zcmu.edu.cn Received: 13 January 2021; Accepted: 16 March 2021 $\begin{array}{ll}\text { Sph: } & \text { sphingosine } \\ \text { SphK1: } & \text { sphingosine kinase } 1\end{array}$

\section{Introduction}

Gastric cancer is a common malignant tumor in the world. The incidence rate and the death rate of gastric cancer are fifth and third in cancers, according to the international agency for cancer research, which is a serious threat to human health. More than $70 \%$ of the new gastric cancer cases occurred in developing countries, and about 50\% occurred in eastern Asia, mainly in China (Ferlay et al., 2015). It is still very urgent work to discover anti gastric cancer drugs and study the anti-cancer mechanism of these drugs.

Arsenic trioxide $\left(\mathrm{As}_{2} \mathrm{O}_{3}\right)$ exhibits broad antitumor activity and is able to reverse tumor cell drug resistance. Moreover, $\mathrm{As}_{2} \mathrm{O}_{3}$ can induce apoptosis by acting on apoptosis-related genes. For instance, it affects the expression of p53, Bcl-2, and caspases (Li et al., 2009; Park and Kim, 2012; Yu et al., 2007), downregulates the expression of cell transcription factor Sox2 (Hui and Zhang, 2011), survivin protein, and phosphorylated Akt protein in the cells (Chiu et al., 2011; Yuan et al., 2011), and inhibits cell proliferation ( $\mathrm{Li}$ et al., 2011). $\mathrm{As}_{2} \mathrm{O}_{3}$ can also 
act on the mitochondria-dependent apoptosis pathway and promote cell apoptosis (Chen et al., 2010).

There have been many studies on $\mathrm{As}_{2} \mathrm{O}_{3}$ inhibiting the proliferation of gastric cancer cells, such as p53 (Liang et al., 2003), Caspase-3 (Jiang et al., 2001), TRF1, and TRF2 (Zhang et al., 2005). However, there is still a lack of research on many other tumor factors such as S1P and SphK1.

Lipids display numerous important biological functions. Notably, abnormal lipid metabolism is closely related to the occurrence of various diseases. For example, S1P is a signaling sphingolipid, which can regulate the cellular calcium balance and stimulate the signaling pathways related to apoptosis and survival of liver myofibroblasts (Yang et al., 2004). S1P also plays a key role in controlling the transport of immune cells and is associated with many cancers and inflammatory diseases (Kunkel et al., 2013; Xie et al., 2017).

SphK1 and SphK2 are involved in the synthesis of S1P. The role of the former is relatively clear, i.e., overexpression of SphK1 can promote the synthesis of S1P as well as improve the proliferation, migration, and invasion of tumor cells (Li et al., 2016; Long et al., 2015). In contrast, Sphk2 is limited to specific tissues, and its functions are not fully understood (Zheng et al., 2019). Generally, SphK1 and S1P can be considered as potential targets for anticancer therapy.

SphK1 is predominantly distributed in the brain, heart, lung, liver, spleen, and hematopoietic immune system and is the most important molecule regulating S1P. SphK1 can be activated by $\mathrm{p}$-ERK1/2 at the Ser225 phosphorylation site. The activity of SphK1 can also be enhanced by upregulating the transcription level (Shida et al., 2008; Doll et al., 2007) and is related both to its phosphorylation form localization in the cells. Numerous studies have shown that SphK1 requires activation and transfer from the cytoplasm to the cell membrane. As demonstrated in Fig. 1, SphK1 is phosphorylated by $\mathrm{p}$-ERK1/2, changing the conformation of the protein. Subsequently, SphK1 binds to the calcium myristoyl switch protein CIB1 in a calcium-dependent

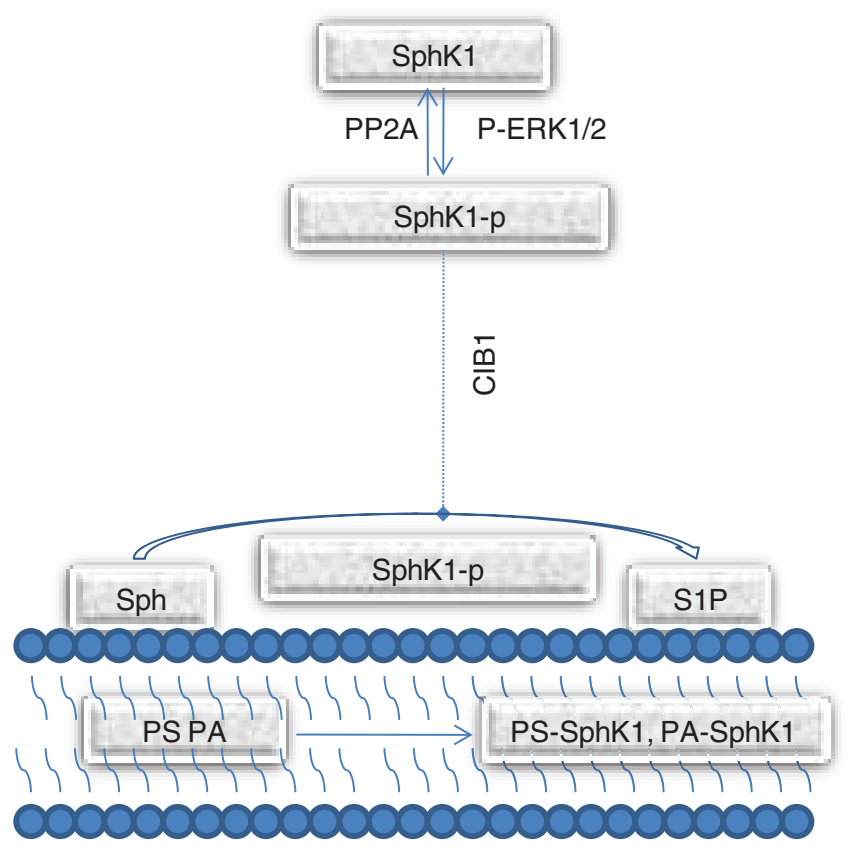

FIGURE 1. The SphK1 phosphorylation and activation pathway. manner and is transported to the cell membrane (Jarman et al., 2010), where it is combined with PS or PA. This enables SphK1 to remain on the membrane and phosphorylate Sph to form S1P (Subramanian et al., 2005).

Our previous studies revealed that $\mathrm{As}_{2} \mathrm{O}_{3}$ could significantly reduce the level of $\mathrm{S} 1 \mathrm{P}$ in the human gastric cancer cell line MGC-803 (Zou et al., 2015). Hence, it was inferred that $\mathrm{As}_{2} \mathrm{O}_{3}$ may decrease the activity of SphK1 and downregulate the synthesis of S1P. Nonetheless, the effects of $\mathrm{As}_{2} \mathrm{O}_{3}$ on SphK1 have never been elucidated. Thus, in this work, we investigated the effect of $\mathrm{As}_{2} \mathrm{O}_{3}$ on SphK1 and the activators of the SphK1-related pathway to determine the mechanism by which $\mathrm{As}_{2} \mathrm{O}_{3}$ reduced the activity of SphK1. Western blotting analysis was employed to detect the protein expression of SphK1, p-ERK1/2, PP2A, and CIB1. Furthermore, qPCR was used to detect the level of SphK1 mRNA, while MDMD-SL was utilized to determine the levels of PS and PA in the cells.

\section{Materials and Methods}

\section{Reagents for cell experiments}

Penicillin, streptomycin, RPMI 1640, protease inhibitor tablets, and FBS were purchased from Invitrogen (Grand Island, USA). $\mathrm{As}_{2} \mathrm{O}_{3}$ was obtained from Sigma-Aldrich (St. Louis, MO, USA) and dissolved in $0.1 \mathrm{M}$ sodium hydroxide to obtain trivalent arsenite (iAs ${ }^{\mathrm{III}}$ ) stock solution. The antibodies for detecting SphK1, p-ERK1/2, PP2A, and CIB1 were acquired from Cell Signaling Technology (Shanghai, China). All other chemicals were of analytical grade.

\section{Reagents for mass spectrometry experiments}

The lipid internal standards were purchased from Avanti Polar Lipids, Inc. (Alabaster, AL, USA), Matreya, Inc. (Pleasant Gap, PA, USA), or $\mathrm{Nu}$ Chek, Inc. (Elysian, MN, USA). The solvents were obtained from Burdick and Jackson (Honeywell International Inc., Muskegon, MI, USA). Other chemicals were analytical grade and were acquired from Sigma-Aldrich (St. Louis, MO, USA) or Fisher Scientific (Pittsburgh, PA, USA).

\section{Cell culture}

The human gastric cancer MGC-803 cell line is one of the representative cells for gastric cancer research. It was reported that the MGC- 803 cell line is the most sensitive to $\mathrm{As}_{2} \mathrm{O}_{3}$ treatment in a variety of tumor cells (Zhang et al., 1999). Therefore, MGC-803 cells were selected for experiments in this article.

Because the human gastric cancer MGC-803 cells were adherent, iAs ${ }^{\text {III }}$ solution was added after the cells adhered to the bottom wall. The MGC-803 cells (lab stock) were seeded at a density of $1.0 \times 10^{6}$ in a T25 flask and were cultured for $12 \mathrm{~h}$ to allow them to adhere to the wall. Following adherence, the cultures were washed twice with PBS, and a fresh medium was added. The cells were subsequently treated with different concentrations of iAs ${ }^{\mathrm{III}}(0.0,2.0$, and $4.0 \mu \mathrm{M})$ and were maintained in a logarithmic growth phase in the RPMI-1640 medium supplemented with $10 \%$ FBS, $100 \mathrm{U} / \mathrm{mL}$ penicillin, and $100 \mu \mathrm{g} / \mathrm{mL}$ streptomycin at $37^{\circ} \mathrm{C}$ for $24 \mathrm{~h}$ under a $5 \% \mathrm{CO}_{2}$ atmosphere. 


\section{Western blot analysis}

The MGC-803 cells were washed twice with phosphatebuffered saline and then lysed for 30 min using the RIPA extraction buffer (Beyotime Institute of Biotechnology, Jiangsu, China) containing freshly prepared protease inhibitors (Merck, Germany). The cells were then centrifuged for $5 \mathrm{~min}$ at $14,000 \mathrm{rpm}$ at $4^{\circ} \mathrm{C}$. The protein concentration in the supernatant was determined by the Bio-Rad microprotein assay using bovine serum albumin as the standard. $40 \mathrm{mg}$ of each protein sample was resolved by $10 \%$ SDS-PAGE and electroblotted onto nitrocellulose membranes (Bio-Rad, Mississauga, ON). The membranes were blocked for $2 \mathrm{~h}$ at room temperature in PBS containing 5\% skim milk and $0.1 \%$ Tween-20 (PBST). The membranes were subsequently incubated with primary antibodies overnight at $4^{\circ} \mathrm{C}$, washed, and incubated with HRP-conjugated secondary antibodies for $1 \mathrm{~h}$ at room temperature. Immunoreactive proteins were detected utilizing an ECL Plus kit (BioRad, Hercules, CA, USA).

\section{Quantitative real-time PCR analysis}

qPCR was employed to evaluate the mRNA expression of SphK1 in MGC-803 cells. $\beta$-Actin was used as the normalizer and the total RNA was isolated utilizing a TRIzol reagent kit (Invitrogen) according to the manufacturer's instructions. The cDNA synthesis was conducted using a reverse transcription kit (TaKaRa). The primer sequences used for qPCR were as follows: forward primer of the SphK1 gene, 5'AGAGTGGGTTCCAAGACACCT-3'; reverse primer of the SphK1 gene, 5'-GGGTGCAGCAAAC-ATCTCAC-3'; forward primer of the GAPDH gene, 5'-CTGGGCTACACTGAGCACC-3'; reverse primer of the GAPDH gene, 5'AAGTGGTCGTTGAGGGCAATG-3'. PCR was performed in triplicate at a final volume of $10 \mu \mathrm{L}$ using real-time PCR Kits (Bio-Rad) according to the manufacturer's instructions. The data were collected and analyzed by an Applied Biosystems 7900HT Fast system. Three independent sets of experiments were performed.

Preparation of lipid extracts from cells

The human gastric cancer MGC-803 cells were washed twice with PBS. $0.3 \mathrm{~mL}$ of distilled water was then added, and the cells were scraped from the dish and transferred into a
$2.0 \mathrm{~mL}$ tube. The cells in the supernatant culture medium were also collected, washed, and combined with the cells scraped from the dish. The cells were collected through centrifugation at $800 \mathrm{rpm}$ for $5 \mathrm{~min}$. Then the cells were homogenized by sonification in $0.5 \mathrm{~mL}$ of ice-cold diluted $(0.1 \times)$ PBS. The protein assay was performed on the homogenates employing a bicinchoninic acid protein assay kit (Pierce, Rockford, IL) using bovine serum albumin as the standard. The lipids were extracted from each sample using the Bligh and Dyer extraction procedure prior to analysis by the methods previously reported by Hu et al. (2015). Briefly, the internal standards were added into each cell sample based on its protein content to normalize the lipid levels as well as to quantify the sample. The lipid extracts were dried using nitrogen gas, redissolved in $1: 1 \mathrm{CHCl}_{3} / \mathrm{MeOH}$ at a concentration of $200 \mu \mathrm{L} / \mathrm{mg}$ protein present in the original sample, capped, and stored at $-20^{\circ} \mathrm{C}$ for MS analysis.

\section{Lipid analysis}

A triple-quadrupole mass spectrometer (Thermo TSQ Quantiva, USA) equipped with an automated nanospray ion source (TriVersa NanoMate, Advion Bioscience Ltd., USA) and operated under the Xcalibur system software was used for the analysis. Identification and quantification of different lipid classes and individual species were conducted by MDMS-SL based on the lipidomics principles.

\section{MS analysis of lipids}

The diluted lipid extract solution was directly injected into the mass spectrometer using the NanoMate device. Lipids are typically composed of several building blocks, including backbones, head groups, and aliphatic chains. In this work, these building blocks were exploited to analyze individual lipid species in the MDMS-SL platform. The lipids were identified by employing two powerful tandem MS techniques (i.e., NLS and PIS) in a mass-ramp fashion (Hu et al., 2015).

\section{Statistical analysis}

Data are presented as the mean \pm SD. Each experiment was performed at least three times. Statistical analysis was performed by the Student's $t$-test. $P$-values of $<0.05$ were considered statistically significant. An asterisk represents $P<0.05$, and two asterisks represent $P<0.01$.

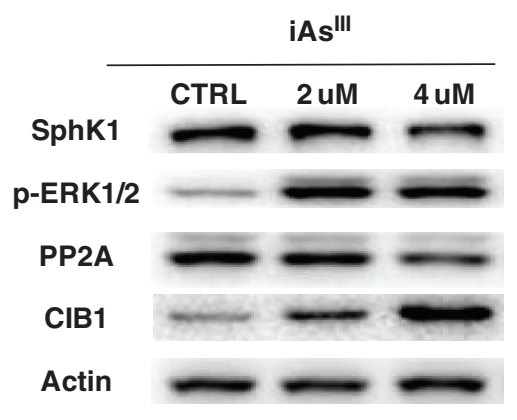

(A)

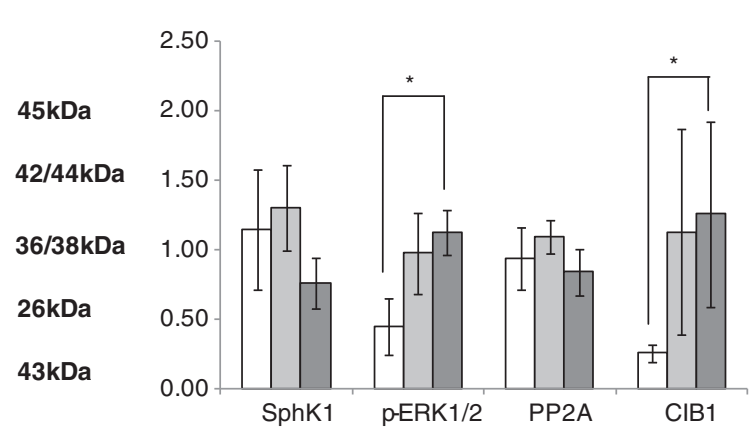

(B)

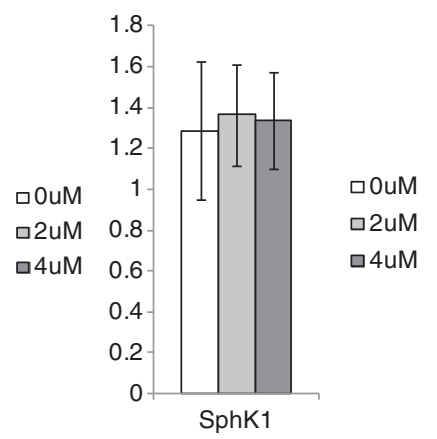

(C)

FIGURE 2. Effects of $\mathrm{iAs}{ }^{\mathrm{III}}$ on the expression of SphK1, p-ERK1/2, PP2A, and CIB1 in MGC-803 cells. (A-B) Western blotting analysis of the expression of SphK1, p-ERK1/2, PP2A, and CIB1 following iAs ${ }^{\mathrm{III}}$ treatment. (C) Quantitative real-time PCR analysis of the SphK1 mRNA expression levels in the MGC-803 cells with different concentrations of iAs ${ }^{\mathrm{III}}(\mathrm{N}=3)$. An asterisk represents $P<0.05$. 


\section{Results}

Western blotting analysis of SphK1, p-ERK1/2, PP2A, and CIB1 as well as QPCR of SphK1

The MGC-803 cells were treated with different concentrations of $\mathrm{iAs}{ }^{\mathrm{II}}$ for $24 \mathrm{~h}$, and the total proteins and RNAs were isolated and analyzed. The changes in the protein expression levels of SphK1, p-ERK1/2, PP2A, and CIB1 were evaluated by western blotting (Figs. $2 \mathrm{~A}$ and $2 \mathrm{~B}$ ). The results revealed that the protein expression level of SphK1 did not change with increasing drug concentration, indicating that $\mathrm{As}_{2} \mathrm{O}_{3}$ did not affect the SphK1 protein synthesis pathway. The expression of SphK1 mRNA was detected by quantitative real-time PCR analysis. The outcomes demonstrated that the mRNA expression level of SphK1 did not significantly change with the increase of $\mathrm{iAs}{ }^{\mathrm{III}}$ concentration (Fig. 2C), suggesting that $\mathrm{As}_{2} \mathrm{O}_{3}$ did not influence the SphK1 transcription synthesis pathway. The protein expression level of p-ERK1/2 increased with increasing concentration of iAs ${ }^{\text {III }}$, which implied that the compound might promote the phosphorylation of SphK1 through p-ERK1/2. Moreover, the protein expression level of CIB1 also increased with increasing $\mathrm{iAs}{ }^{\mathrm{III}}$ concentration. This indicated that $\mathrm{As}_{2} \mathrm{O}_{3}$ might promote the further transfer of activated SphK1 to the cell membrane through CIB1.

The iAs ${ }^{\mathrm{III}}$ significantly increased the levels of $\mathrm{p}$-ERK1/2 and CIB1 at $4.0 \mu \mathrm{M}$, indicating that a relatively high concentration of iAs ${ }^{\mathrm{III}}$ is needed to stimulate the increase of p-ERK1/2 and CIB1.
There were no significant increase levels of p-ERK1/2 and CIB1 when the concentration of $\mathrm{iAs}{ }^{\mathrm{III}}$ increased from $2.0 \mu \mathrm{M}$ to 4.0 $\mu \mathrm{M}$, which indicated that $\mathrm{p}$-ERK1/2 and CIB1 were not sensitive to the increased concentration of $\mathrm{iAs}^{\mathrm{III}}$. The changes in the levels of $\mathrm{p}$-ERK1/2 and CIB1 suggested that $\mathrm{As}_{2} \mathrm{O}_{3}$ may promote the activation of SphK1.

Quantitative determination of PS in cells

The contents of PS and PA were measured by MS before and after the $\mathrm{As}_{2} \mathrm{O}_{3}$ treatment. The effects of $\mathrm{As}_{2} \mathrm{O}_{3}$ on the contents of PS and PA were investigated at an iAs ${ }^{\mathrm{III}}$ dose of $0.0,2.0$, and $4.0 \mu \mathrm{M}$.

The types and contents of PS detected in the human gastric cancer cell line MGC-803 are summarized in Table 1. As it can be seen, overall, 19 kinds of PS were detected and quantified. The content of individual PS ranged from $0.16 \pm$ $0.02 \mathrm{nmol} / \mathrm{mg}$ protein (PS20:0-20:3/18:0-22:3) to $16.12 \pm$ $0.77 \mathrm{nmol} / \mathrm{mg}$ protein (PS18:0-18:1) in untreated cells. The contents of most kinds of PS decreased in cells treated with $\mathrm{As}_{2} \mathrm{O}_{3}$. The total content of PS was determined at $36.36 \pm$ $1.13 \mathrm{nmol} / \mathrm{mg}$ protein in untreated cells, $27.83 \pm 1.09 \mathrm{nmol} /$ mg protein in cells treated with $2.0 \mu \mathrm{M}$ of iAs ${ }^{\mathrm{III}}$, and $25.74 \pm$ $0.39 \mathrm{nmol} / \mathrm{mg}$ protein in cells treated with $4.0 \mu \mathrm{M}$ of $\mathrm{iAs}{ }^{\mathrm{III}}$. It was found that the content of PS evidently decreased following treatment with $\mathrm{As}_{2} \mathrm{O}_{3}$.

The iAs ${ }^{\text {III }}$ significantly decreased the levels of some PS at $2.0 \mu \mathrm{M}$, indicating that a relatively low concentration of $\mathrm{iAs} \mathrm{sI}^{\mathrm{III}}$ is needed to stimulate the decrease of PS. There were still some

TABLE 1

Effect of $\mathrm{As}_{2} \mathrm{O}_{3}$ on the content (nmol/mg protein) of PS in the human gastric cancer cell line MGC-803 $(\mathrm{N}=3)$

\begin{tabular}{|c|c|c|c|c|c|}
\hline PS species & $\begin{array}{l}\text { Monoisotopic } \\
\text { mass [PS-H]- }\end{array}$ & iAs $^{\text {III }}(0.0 \mu \mathrm{M})$ & $\begin{array}{l}\mathrm{iAs}^{\mathrm{III}}(2.0 \mu \mathrm{M}) \\
(\text { Difference } 0.0-2.0 \mu \mathrm{M})\end{array}$ & $\begin{array}{l}\text { iAs }^{\text {III }}(4.0 \mu \mathrm{M}) \\
(\text { Difference } 0.0-4.0 \mu \mathrm{M})\end{array}$ & $\begin{array}{l}\text { Difference } \\
(2.0-4.0 \mu \mathrm{M})\end{array}$ \\
\hline $16: 0-16: 1$ & 732.48 & $0.31 \pm 0.05$ & $0.19 \pm 0.02 \downarrow^{*}$ & $0.09 \pm 0.01 \downarrow^{* *}$ & $\downarrow^{* *}$ \\
\hline P16:0-18:0 & 746.53 & $0.17 \pm 0.02$ & $0.10 \pm 0.04 \downarrow$ & $0.08 \pm 0.01 \downarrow^{* *}$ & $\downarrow$ \\
\hline $16: 0-18: 2$ & 758.50 & $0.38 \pm 0.06$ & $0.24 \pm 0.08 \downarrow$ & $0.18 \pm 0.02 \downarrow^{* *}$ & $\downarrow$ \\
\hline $16: 0-18: 1$ & 760.51 & $5.31 \pm 0.35$ & $3.49 \pm 0.27 \downarrow^{* *}$ & $2.96 \pm 0.10 \downarrow^{* *}$ & $\downarrow^{*}$ \\
\hline $16: 0-18: 0$ & 762.53 & $0.19 \pm 0.03$ & $0.15 \pm 0.07 \downarrow$ & $0.10 \pm 0.01 \downarrow^{* *}$ & $\downarrow$ \\
\hline P18:0-18:0 & 774.57 & $0.98 \pm 0.22$ & $0.71 \pm 0.02 \downarrow$ & $0.58 \pm 0.05 \downarrow^{*}$ & $\downarrow^{*}$ \\
\hline $18: 1-18: 2$ & 784.51 & $0.29 \pm 0.01$ & $0.20 \pm 0.04 \downarrow^{*}$ & $0.17 \pm 0.02 \downarrow^{* *}$ & $\downarrow$ \\
\hline $18: 0-18: 2$ & 786.53 & $5.14 \pm 0.65$ & $3.40 \pm 0.03 \downarrow^{* *}$ & $2.92 \pm 0.08 \downarrow^{* *}$ & $\downarrow^{* *}$ \\
\hline $18: 0-18: 1$ & 788.54 & $16.12 \pm 0.77$ & $13.71 \pm 0.78 \downarrow^{*}$ & $13.52 \pm 0.43 \downarrow^{* *}$ & $\downarrow$ \\
\hline $18: 0-20: 4$ & 810.53 & $0.87 \pm 0.16$ & $0.55 \pm 0.05 \downarrow^{*}$ & $0.51 \pm 0.05 \downarrow^{*}$ & $\downarrow$ \\
\hline $18: 0-20: 2$ & 814.56 & $1.14 \pm 0.18$ & $0.86 \pm 0.05 \downarrow$ & $0.84 \pm 0.03 \downarrow^{*}$ & $\downarrow$ \\
\hline $18: 0-20: 1$ & 816.58 & $0.71 \pm 0.10$ & $0.56 \pm 0.03 \downarrow$ & $0.49 \pm 0.06 \downarrow^{*}$ & $\downarrow$ \\
\hline $18: 0-22: 6$ & 834.53 & $0.87 \pm 0.16$ & $0.63 \pm 0.04 \downarrow$ & $0.48 \pm 0.07 \downarrow^{*}$ & $\downarrow^{*}$ \\
\hline $18: 0-22: 5$ & 836.54 & $0.82 \pm 0.17$ & $0.57 \pm 0.08 \downarrow$ & $0.52 \pm 0.01 \downarrow^{*}$ & $\downarrow$ \\
\hline $20: 0-20: 4 / 18: 0-22: 4$ & 838.56 & $0.57 \pm 0.03$ & $0.57 \pm 0.05 \downarrow$ & $0.45 \pm 0.07 \downarrow^{*}$ & $\downarrow$ \\
\hline $20: 0-20: 3 / 18: 0-22: 3$ & 840.58 & $0.16 \pm 0.02$ & $0.13 \pm 0.03 \downarrow$ & $0.12 \pm 0.05 \downarrow^{*}$ & $\downarrow$ \\
\hline $20: 0-20: 2 / 18: 0-22: 2$ & 842.59 & $0.5 \pm 0.05$ & $0.43 \pm 0.04 \downarrow$ & $0.44 \pm 0.03 \downarrow$ & - \\
\hline $20: 0-20: 1 / 18: 0-22: 1$ & 844.61 & $0.29 \pm 0.18$ & $0.18 \pm 0.03 \downarrow$ & $0.16 \pm 0.03 \downarrow$ & $\downarrow$ \\
\hline TOTAL & & $36.36 \pm 1.13$ & $27.83 \pm 1.09 \downarrow^{* *}$ & $25.74 \pm 0.39 \downarrow^{* *}$ & $\downarrow^{*}$ \\
\hline
\end{tabular}

Note: An asterisk represents $P<0.05$, and two asterisks represent $P<0.01$. 
significant decrease levels of PS when the concentration of iAs ${ }^{I I I}$ increased from $2.0 \mu \mathrm{M}$ to $4.0 \mu \mathrm{M}$, which indicated that PS was sensitive to the increased concentration of iAs ${ }^{\mathrm{III}}$. The changes in the levels of PS suggested that $\mathrm{As}_{2} \mathrm{O}_{3}$ may reduce the activation of SphK1.

\section{Quantitative determination of PA in cells}

The types and contents of PA detected in the human gastric cancer cell line MGC-803 are summarized in Table 2. As it can be seen, in total, six kinds of PA were detected and quantified. The content of individual PA ranged from $63.73 \pm 0.79 \mathrm{pmol} / \mathrm{mg}$ protein (PA16:0-16:1PA) to $897.88 \pm 15.02 \mathrm{pmol} / \mathrm{mg}$ protein (PA18:0-18:1) in untreated cells. Although the content of PA16:0-16:0 increased after being treated with $\mathrm{As}_{2} \mathrm{O}_{3}$, the content of other types of PA decreased following treatment. Notably, the total content of PA also decreased after treatment with $\mathrm{As}_{2} \mathrm{O}_{3}$. The content of total PA was determined at $1849.10 \pm 27.34 \mathrm{pmol} / \mathrm{mg}$ protein in untreated cells, $1765.19 \pm 53.90 \mathrm{pmol} / \mathrm{mg}$ protein in cells treated with $2.0 \mu \mathrm{M}$ iAs ${ }^{\mathrm{III}}$, and $1605.61 \pm 34.21$ $\mathrm{pmol} / \mathrm{mg}$ protein in cells treated with $4.0 \mu \mathrm{mol}$ iAs ${ }^{\mathrm{III}}$.

The iAs ${ }^{\text {III }}$ significantly decreased the levels of some major PA at $2.0 \mu \mathrm{M}$, indicating that a relatively low concentration of $\mathrm{iAs}^{\mathrm{III}}$ is needed to stimulate the decrease of PA. There were still some significant decrease levels of PA when the concentration of iAs ${ }^{\mathrm{III}}$ increased from $2.0 \mu \mathrm{M}$ to $4.0 \mu \mathrm{M}$, which indicated that PA was sensitive to the increased concentration of $\mathrm{iAs}^{\mathrm{III}}$. The changes in the levels of PA suggested that $\mathrm{As}_{2} \mathrm{O}_{3}$ may reduce the activation of SphK1.

\section{Discussion}

$\mathrm{As}_{2} \mathrm{O}_{3}$ could enhance the levels of p-ERK1/2 and CIB1 in the pathway, indicating that $\mathrm{As}_{2} \mathrm{O}_{3}$ might promote the activation of SphK1. In contrast, $\mathrm{As}_{2} \mathrm{O}_{3}$ decreased the levels of PS and PA in the cells, limiting the binding of SphK1 to PS and PA on the cell membrane simultaneously limiting the location of SphK1 and then decreasing the activity of SphK1.

The results showed that $2 \mu \mathrm{M}$ iAs ${ }^{\mathrm{III}}$ significantly reduced the levels of some PS and PA in cells $(P<0.05)$, while there was no significant difference in the levels of p-ERK1/2 and CIB1. $4 \mu \mathrm{M}$ iAs ${ }^{\mathrm{III}}$ significantly reduced the levels of some PS and PA $(P<0.01)$ and increased the level of p-ERK1/2 and
CIB1 $(P<0.05)$ in cells. It showed that $\mathrm{As}_{2} \mathrm{O}_{3}$ reduced the levels of PS and PA at a relatively low concentration and increased the levels of p-ERK1/2 and CIB1 at a relatively high concentration. The reduction rates of PS and PA were greater than the increased rates of p-ERK and CIB1. Combined with the previous results of reduced level of SphK1 production S1P, therefore, we propose that the inhibitory effect is stronger than the enhancing effect, and the inhibition of SphK1 occurred earlier.

The method of determining the activity of extracellular SphK1 is to purify SphK1 from cells, then add the substrate and determine the product (Pitson et al., 2000). However, the activity of SphK1 inside cells depends on its binding with PS or PA and its localization on the cell membrane. There is still no method to directly determine the activity of SphK1 inside cells. Due to the limitations of the detection method, the specific value of the increased or decreased activity could not be measured. We could only describe the trend of increase or decrease of activity.

It has been reported that $\mathrm{p}$-ERK1/2 provides a phosphate group for $\mathrm{SphK1}$, but $\mathrm{p}$-ERK1/2 also provides a phosphate group for other proteins. And CDK2 was found to phosphorylate SphK1 also with much lower efficiency than p-ERK1/2 (Pitson et al., 2003). As for the influence of p-ERK1/2 by $\mathrm{As}_{2} \mathrm{O}_{3}$ in the SphK1 activation pathway, we plan to carry out more research on ERK signaling pathway in the future.

It was proposed that the ability of $\mathrm{As}_{2} \mathrm{O}_{3}$ decreasing the activity of SphK1 may be stronger than its ability to increase the activity of SphK1, which resulting in an overall decrease in the activity of SphK1. Our previous investigations inferred that $\mathrm{As}_{2} \mathrm{O}_{3}$ inhibited the activity of SphK1; based on this work, it was suggested that $\mathrm{As}_{2} \mathrm{O}_{3}$ could inhibit the activity of SphK1 by decreasing the cellular levels of PS and PA. We deciphered that the inhibitory effect of $\mathrm{As}_{2} \mathrm{O}_{3}$ was important. $\mathrm{As}_{2} \mathrm{O}_{3}$ owed the ability to inhibit the activity of SphK1 and reduce the production of S1P in the cells and finally inhibit the proliferation of tumor cells. However, $\mathrm{As}_{2} \mathrm{O}_{3}$ might show its carcinogenicity through the enhancement of p-ERK1/2 and CIB1 levels in cells.

SphK1 has received much attention due to its involvement in a variety of cancer and inflammatory diseases, such as rheumatoid arthritis, diabetes, and neurodegenerative diseases. SphK1 is highly expressed in various types of cancer.

\section{TABLE 2}

Effect of $\mathrm{As}_{2} \mathrm{O}_{3}$ on the content (pmol/mg protein) of PA in the human gastric cancer cell line MGC-803 $(\mathrm{N}=3$ )

\begin{tabular}{|c|c|c|c|c|c|}
\hline PA species & $\begin{array}{l}\text { Monoisotopic } \\
\text { mass [PA-H]- }\end{array}$ & $\mathrm{iAs}^{\mathrm{III}}(0.0 \mu \mathrm{M})$ & $\begin{array}{l}\text { iAs }^{\mathrm{III}}(2.0 \mu \mathrm{M}) \\
(\text { Difference } 0.0-2.0 \mu \mathrm{M})\end{array}$ & $\begin{array}{l}\text { iAs }{ }^{\mathrm{III}}(4.0 \mu \mathrm{M}) \\
(\text { Difference } 2.0-4.0 \mu \mathrm{M})\end{array}$ & $\begin{array}{l}\text { Difference } \\
(2.0-4.0 \mu \mathrm{M}) \\
\end{array}$ \\
\hline $16: 0-16: 1$ & 645.45 & $63.73 \pm 0.79$ & $73.67 \pm 10.94 \uparrow$ & $48.62 \pm 2.26 \downarrow^{* *}$ & $\downarrow^{*}$ \\
\hline $16: 0-16: 0$ & 647.47 & $99.74 \pm 7.35$ & $129.64 \pm 10.82 \uparrow$ & $120.16 \pm 10.25 \uparrow$ & $\downarrow$ \\
\hline $16: 0-18: 1$ & 673.48 & $385.90 \pm 2.14$ & $355.00 \pm 13.57 \downarrow^{\star}$ & $292.36 \pm 9.14 \downarrow^{* *}$ & $\downarrow^{* *}$ \\
\hline $18: 0-18: 2 / 18: 1-18: 1$ & 699.50 & $264.74 \pm 14.75$ & $265.78 \pm 26.36-$ & $223.83 \pm 16.17 \downarrow^{*}$ & $\downarrow$ \\
\hline $18: 0-18: 1$ & 701.51 & $897.88 \pm 15.02$ & $815.33 \pm 30.76 \downarrow^{*}$ & $808.99 \pm 8.12 \downarrow^{*}$ & $\downarrow$ \\
\hline 18:0-20:3 & 725.51 & $137.78 \pm 10.94$ & $125.77 \pm 34.35 \downarrow$ & $114.65 \pm 10.41 \downarrow^{*}$ & $\downarrow$ \\
\hline TOTAL & & $1849.10 \pm 27.34$ & $1765.19 \pm 53.90 \downarrow$ & $1605.61 \pm 34.21 \downarrow^{* *}$ & $\downarrow^{*}$ \\
\hline
\end{tabular}

Note: An asterisk represents $P<0.05$, and two asterisks represent $P<0.01$. 
Upregulation of SphK1 is related to tumor angiogenesis and resistance to radiotherapy and chemotherapy. Overexpression of SphK1 is considered as a potential drug target in malignant tumors of breast, lung, uterus, ovary, kidney, and leukemia. According to the latest research, through virtual high-throughput screening of 90000 kinds of natural products, two kinds of natural products were selected as potential inhibitors of SphK1 to develop effective treatment methods for SphK1 related diseases (including cancer) (Jairajpuri et al., 2020). In this study, the results of $\mathrm{As}_{2} \mathrm{O}_{3}$ on SphK1 can provide a reference for the research and development of SphK1 inhibitors.

PS widely exists in the eukaryotic cell membrane and has important biological functions. Studies have shown that PS is widely expressed on the surface of tumor cells, and the expression level is positively correlated with the malignant degree of tumor cells (Riedl et al., 2011). At present, some anticancer drugs, such as antimicrobial peptides, have been designed with PS as the target. These peptides can specifically bind to PS on the surface of tumor cells, thus reducing the content of PS on the surface of tumor cells. In this study, the results show that $\mathrm{As}_{2} \mathrm{O}_{3}$ can reduce the content of PS in cells, which shows that $\mathrm{As}_{2} \mathrm{O}_{3}$ can not only reduce the activity of SphK1 by reducing the level of PS but also can directly act on cancer cells by reducing the content of PS.

PA is an important second messenger and plays a role in many cell functions. PA is involved in a wide range of cellular processes, including vesicular transport, cytoskeletal organization, secretion, cell proliferation, and survival (Liu et al., 2013). PA can not only exert biological activity through binding proteins (Delon et al., 2004) but also produce lysophosphatidic acid (LPA) which can promote tumor growth and metastasis (Aoki, 2004). In this study, the results show that $\mathrm{As}_{2} \mathrm{O}_{3}$ can not only reduce the activity of SphK1 by reducing the level of PA but also may reduce the level of LPA in cells.

\section{Conclusion}

$\mathrm{As}_{2} \mathrm{O}_{3}$ exhibited no effects on the protein and mRNA expression of SphK1 in the MGC-803 cells. However, $\mathrm{As}_{2} \mathrm{O}_{3}$ could enhance the levels of p-ERK1/2 and CIB1 in the SphK1 activation pathway, indicating that it might increase the phosphorylation and activation of SphK1. $\mathrm{As}_{2} \mathrm{O}_{3}$ could also considerably reduce the expression of PS and PA in the cells, which inhibits the binding and location of SphK1, which reduces the activity of SphK1. Since our previous investigations revealed that $\mathrm{As}_{2} \mathrm{O}_{3}$ could significantly reduce the level of SphK1 products $\mathrm{S} 1 \mathrm{P}$ and inferred that $\mathrm{As}_{2} \mathrm{O}_{3}$ inhibited the activity of SphK1, it was proposed that the ability of $\mathrm{As}_{2} \mathrm{O}_{3}$ to decrease the activity of SphK1 was stronger than its ability to increase the activity of SphK1, which resulting in an overall decrease in the activity of SphK1. Based on this work, it was suggested that $\mathrm{As}_{2} \mathrm{O}_{3}$ could inhibit the activity of SphK1 by decreasing the cellular levels of PS and PA. Furthermore, the SphK1 phosphorylation process also needs to be more investigated in the future to better understand the mechanism of $\mathrm{As}_{2} \mathrm{O}_{3}$ on SphK1 in MGC-803 cells.
Availability of Data and Materials: All data generated or analyzed during this study are included in this published article.

Authors' Contribution: The authors confirm contribution to the paper as follows: study conception and design: Xiaoqiong Ma; data collection: Pei Liu; analysis and interpretation of results: Zhe Chen, Pei Liu; draft manuscript preparation: Xiaoqiong Ma. All authors reviewed the results and approved the final version of the manuscript.

Ethics Approval: The experiments in this work did not involve human subjects, animals, or plants.

Funding Statement: This work was funded by the Natural Science Foundation of the Zhejiang Province, Grant No. LY17H280006 and the National Natural Science Foundation of China, Grant No. 81803776.

Conflicts of Interest: The authors declare that they have no conflict of interest to report regarding the present study.

\section{References}

Aoki J (2004). Mechanisms of lysophosphatidic acid production. Seminars in Cell \& Developmental Biology 15: 477-489. DOI 10.1016/j.semcdb.2004.05.001.

Chen M, Yang P, Ye Y, Hu D, Chen M (2010). Arsenic trioxide induces apoptosis in uveal melanoma cells through the mitochondrial pathway. American Journal of Chinese Medicine 38: 1131-1142. DOI 10.1142/S0192415X10008524.

Chiu H, Ho Y, Wang Y (2011). Arsenic trioxide induces autophagy and apoptosis in human glioma cells in vitro and in vivo through downregulation of surviving. Journal of Molecular Medicine 89: 927-941. DOI 10.1007/s00109-011-0763-1.

Delon C, Manifava M, Wood E, Thompson D, Krugmann S, Pyne S, Ktistakis NT (2004). Sphingosine kinase 1 is an intracellular effector of phosphatidic acid. Journal of Biological Chemistry 279: 44763-44774. DOI 10.1074/jbc.M405771200.

Doll F, Pfeilschifter J, Huwiler A (2007). Prolactin upregulates sphingosine kinase- 1 expression and activity in the human breast cancer cell line MCF7 and triggers enhanced proliferation and migration. Endocrine-Related Cancer 14: 325-335. DOI 10.1677/ERC-06-0050.

Ferlay J, Soerjomataram I, Dikshit R, Eser S, Mathers C, Rebelo M, Parkin DM, Forman D, Bray F (2015). Cancer incidence and mortality worldwide: Sources, methods and major patterns in GLOBOCAN 2012. International Journal of Cancer 136: E359-E386. DOI 10.1002/ijc.29210.

Hu C, Wang Y, Fan Y, Li H, Wang C, Zhang J, Zhang S, Han X, Wen C (2015). Lipidomics revealed idiopathic pulmonary fibrosisinduced hepatic lipid disorders corrected with treatment of baicalin in a murine model. AAPS Journal 17: 711-722. DOI 10.1208/s12248-014-9714-4.

Hui S, Zhang S (2011). Arsenic trioxide regulates the apoptosis of glioma cell and glioma stem cell via down-regulation of stem cell marker Sox2. Biochemical \& Biophysical Research Communications 410: 692-697. DOI 10.1016/j.bbrc.2011.06.060.

Jairajpuri DS, Mohammad T, Adhikari K, Gupta P, Hassan MI (2020). Identification of sphingosine kinase-1 inhibitors from bioactive natural products targeting cancer therapy. ACS Omega 5: 14720-14729. DOI 10.1021/acsomega.0c01511.

Jarman K, Moretti P, Zebol J, Pitson S (2010). Translocation of sphingosine kinase 1 to the plasma membrane is mediated 
by calcium- and integrin-binding protein 1. Journal of Biological Chemistry 285: 483-492. DOI $10.1074 / \mathrm{jbc}$. M109.068395.

Jiang X, Wong B, Yuen S, Jiang S, Cho C, Lai K, Lin M, Kung H, Lam S (2001). Arsenic trioxide induces apoptosis in human gastric cancer cells through up-regulation of p53 and activation of caspase-3. International Journal of Cancer 91: 173-179. DOI 10.1002/10970215(200002)9999:9999<::AID-IJC1039>3.0.CO;2-D.

Kunkel G, Maceyka M, Milstien S, Spiegel S (2013). Targeting the sphingosine-1-phosphate axis in cancer, inflammation and beyond. Nature Reviews Drug Discovery 12: 688-702. DOI 10.1038/nrd4099.

Li HM, Long Y, Qing C, Yu M, Li ZH, Zhang XM, Li XJ, Chen YJ, Zhang YL, Liang Y (2011). Arsenic trioxide induces apoptosis of Burkitt lymphoma cell lines through multiple apoptotic pathways and triggers antiangiogenesis. Oncology Research Featuring Preclinical \& Clinical Cancer Therapeutics 19: 149-163. DOI 10.3727/096504011X12935427587885.

Li J, Song Z, Wang Y, Yin Y, Liu Y, Yuan R, Nan X (2016). Overexpression of SphK1 enhances cell proliferation and invasion in triple-negative breast cancer via the PI3K/AKT signaling pathway. Tumor Biology 37: 10587-10593. DOI 10.1007/s13277-016-4954-9.

Li Y, Qu X, Qu J, Zhang Y, Liu J, Teng Y, Hu X, Hou K, Liu Y (2009). Arsenic trioxide induces apoptosis and G2/M phase arrest by inducing $\mathrm{Cbl}$ to inhibit PI3K/Akt signaling and thereby regulate p53 activation. Cancer Letters 284: 208-215. DOI 10.1016/j.canlet.2009.04.035

Liang XQ, Cao EH, Zhang Y, Qin JF (2003). P53-induced gene 11 (PIG11) involved in arsenic trioxide-induced apoptosis in human gastric cancer MGC-803 cells. Oncology Reports 10: 1265-1269.

Liu Y, Su Y, Wang X (2013). Phosphatidic acid-mediated signaling. In: Capelluto D (eds.), pp. 159-176. Lipid-mediated protein signaling. advances in experimental medicine and biology. Dordrecht: Springer.

Long J, Xie Y, Yin J, Lu W, Fang S (2015). SphK1 promotes tumor cell migration and invasion in colorectal cancer. Tumor Biology 446: 428-432.

Park WH, Kim SH (2012). Arsenic trioxide induces human pulmonary fibroblast cell death via the regulation of Bcl-2 family and caspase-8. Molecular Biology Reports 39: 43114318. DOI 10.1007/s11033-011-1218-z.

Pitson SM, D'andrea RJ, Vandeleur L, Moretti PA, Xia P, Gamble JR, Vadas MA, Wattenberg BW (2000). Human sphingosine kinase: Purification, molecular cloning and characterization of the native and recombinant enzymes. Biochemical Journal 350: 429-441. DOI 10.1042/bj3500429.

Pitson SM, Moretti PAB, Zebol JR, Lynn HE, Xia P, Vadas MA, Wattenberg BW (2003). Activation of sphingosine kinase 1 by ERK1/2-mediated phosphorylation. EMBO Journal 22: 5491-5500. DOI 10.1093/emboj/cdg540.

Riedl S, Rinner B, Asslaber M, Schaider H, Walzer S, Novak A, Lohner K, Zweytick D (2011). In search of a novel targetPhosphatidylserine exposed by non-apoptotic tumor cells and metastases of malignancies with poor treatment efficacy. Biochimica et Biophysica Acta 1808: 2638-2645. DOI 10.1016/j.bbamem.2011.07.026.

Shida D, Takabe K, Kapitonov D, Milstien S, Spiegel S (2008). Targeting SphK1 as a new strategy against cancer. Current Drug Targets 9: 662-673. DOI 10.2174/138945008785132402.

Subramanian P, Stahelin R, Szulc Z, Bielawska A, Cho W, Chalfant C (2005). Ceramide 1-phosphate acts as a positive allosteric activator of group IVA cytosolic phospholipase A2 alpha and enhances the interaction of the enzyme with phosphatidylcholine. Journal of Biological Chemistry 280: 17601-17607. DOI 10.1074/jbc.M414173200.

Xie Z, Liu H, Geng M (2017). Targeting sphingosine-1-phosphate signaling for cancer therapy. Science China Life Sciences 60: 585-600. DOI 10.1007/s11427-017-9046-6.

Yang J, Yu Y, Sun S, Duerksen-Hughes P (2004). Ceramide and other sphingolipids in cellular responses. Cell Biochemistry \& Biophysics 40: 323-350. DOI 10.1385/CBB:40:3:323.

Yu J, Qian H, Li Y, Wang Y, Zhang X, Liang X, Fu M, Lin C (2007). Therapeutic effect of arsenic trioxide (As2O3) on cervical cancer in vitro and in vivo through apoptosis induction. Cancer Biology \& Therapy 6: 580-586. DOI 10.4161/cbt.6.4.3887.

Yuan Z, Wang F, Zhao Z, Zhao X, Qiu J, Nie C, Wei Y (2011). BIMmediated AKT phosphorylation is a key modulator of arsenic trioxide-induced apoptosis in cisplatin-sensitive and -resistant ovarian cancer cells. PLoS One 6: e20586. DOI 10.1371/journal.pone.0020586.

Zhang TC, Cao EH, Li JF, Ma W, Qin JF (1999). Induction of apoptosis and inhibition of human gastric cancer MGC-803 cell growth by arsenic trioxide. European Journal of Cancer 35: 1258-1263. DOI 10.1016/S0959-8049(99)00106-9.

Zhang Y, Cao EH, Qin JF (2005). Up-regulation of telomere-binding TRF1, TRF2 related to reactive oxygen species induced by As2O3 in MGC-803 cells. European Journal of Pharmacology 516: 1-9. DOI 10.1016/j.ejphar.2005.04.022.

Zheng X, Li W, Ren L, Liu J, Pang X, Chen X, Kang D, Wang J, Du G (2019). The sphingosine kinase-1/sphingosine-1-phosphate axis in cancer: Potential target for anticancer therapy. Pharmacology \& Therapeutics 195: 85-99. DOI 10.1016/j. pharmthera.2018.10.011.

Zou J, Ma X, Zhang G, Shen L, Zhou L, Yu Y, Zhu F, Chen Z (2015). Evaluation of the change in sphingolipids in the human multiplemyeloma cell line U266 and gastric cancer cell line MGC-803 treatedwith arsenic trioxide. Journal of Chromatography $B$ 1004: $98-107$. DOI $10.1016 / j$. jchromb.2015.09.015. 